\title{
UJI EFEK EKSTRAK ETANOL DAUN JAMBU BIJI (Psidium guajava L) TERHADAP KADAR KOLESTEROL TOTAL TIKUS WISTAR (Rattus norvegicus)
}

\author{
${ }^{1}$ Irianto Girik Allo \\ ${ }^{2}$ Pemsi Mona Wowor \\ ${ }^{2}$ Henoch Awaloei
}

\author{
${ }^{1}$ Kandidat Skripsi Fakultas Kedokteran Universitas Sam Ratulangi Manado \\ ${ }^{2}$ Bagian Farmakologi dan Terapi Fakultas Kedokteran Universitas Sam Ratulangi Manado \\ Email: iriantogirikallo@yahoo.com
}

\begin{abstract}
This research aims to determine the effect of ethanol extract of guava leaves on levels of total cholesterol of rat that is induced propylthiouracil. This was an experimental research. The sample used was 15 rats were divided into 5 groups ( 1 group is consist of 3 rats), namely: 1) positive control, 2) extract dose of $200 \mathrm{mg} / \mathrm{kgBB}, 3$ ) extract dose of 400 $\mathrm{mg} / \mathrm{kgBB}$, 4) extract dose of $800 \mathrm{mg} / \mathrm{kgBB}$ and 5) negative control. Group 1 to 4 are given propylthiouracil given for 14 days, then given treatment appropiate with the group. The result show that: 1) the average of total cholesterol levels increased after administration propylthiouracil from $156.34 \mathrm{mg} / \mathrm{dL}$ to $247.84 \mathrm{mg} / \mathrm{dL}$, 2) at a dose of $200 \mathrm{mg} / \mathrm{kgBB}, 400$ $\mathrm{mg} / \mathrm{kgBB}$ and $800 \mathrm{mg} / \mathrm{kgBB}$ showed a decline in total cholesterol levels by $32.73 \%, 58.73 \%$ and $47.26 \%, 3$ ) the positive control decreased total cholesterol levels by $39.46 \%$ and 4 ) total cholesterol levels on negative is unstable (there are up and some are down). The result of this research concluse that: guava leaf extract at dose of $200 \mathrm{mg} / \mathrm{kgBB}, 400 \mathrm{mg} / \mathrm{kgBB}$ and $800 \mathrm{mg}$ $\mathrm{kgBB}$ have an effect in lowering total cholesterol of rat had been induced prophylthiouracil.

Keywords: guava leaves, total cholesterol.
\end{abstract}

\begin{abstract}
Abstrak: Penelitian ini bertujuan untuk mengetahui efek dari ekstrak etanol daun jambu biji terhadap kadar kolesterol total tikus wistar yang diinduksi propiltiourasil. Penelitian ini merupakan penelitian eksperimental. Sampel yang digunakan berjumlah 15 tikus wistar yang dibagi menjadi 5 kelompok (1 kelompok terdiri dari 3 tikus wistar), yaitu: 1) kontrol positif, 2) ekstrak dosis $200 \mathrm{mg} / \mathrm{kgBB}$, 3) ekstrak dosis $400 \mathrm{mg} / \mathrm{kgBB}$, 4) ekstrak dosis $800 \mathrm{mg} / \mathrm{kgBB}$ dan 5) kontrol negatif. Kelompok 1 sampai 4 diberikan propiltiourasil selama 14 hari, kemudian diberikan perlakuan sesuai kelompoknya. Hasil penelitian yang diperoleh: 1) ratarata kadar kolesterol total meningkat setelah pemberian propiltiourasil yaitu dari 156,34 $\mathrm{mg} / \mathrm{dL}$ menjadi 247,84 mg/dL, 2) pada dosis $200 \mathrm{mg} / \mathrm{kgBB}$, $400 \mathrm{mg} / \mathrm{kgBB}$ dan $800 \mathrm{mg} / \mathrm{kgBB}$ menunjukkan terjadi penurunan kadar kolesterol total sebesar 32,73\%, 58,73\% dan 47,26\%, 3) pada kontrol positif terjadi penurunan kadar kolesterol total sebesar 39,46\% dan 4) kadar kolesterol total pada kelompok negatif tidak stabil (ada yang naik dan ada yang turun). Hasil penelitian ini menyimpulkan bahwa ekstrak daun jambu biji pada dosis $200 \mathrm{mg} / \mathrm{kgBB}, 400$ $\mathrm{mg} / \mathrm{kgBB}$ dan $800 \mathrm{mg} / \mathrm{kgBB}$ mempunyai efek dalam menurunkan kadar kolesterol total tikus wistar yang telah diinduksi propiltiourasil.
\end{abstract}

Kata kunci: daun jambu biji, kadar kolesterol total.

Kehidupan modern saat ini menuntut seseorang bergerak cepat untuk memenuhi berbagai kebutuhan hidup dan membuat tubuhnya berada dalam kondisi kelelahan, kurang tidur, stress dan depresi yang menyebabkan penurunan daya tahan tubuh sehingga tubuh rentan terserang penyakit. ${ }^{1}$ Di alam Indonesia terdapat kurang lebih 
30.000 jenis tanaman dari sekitar 40.000 jenis tanaman di dunia, baru ditemukan 940 jenis di antaranya yang merupakan tanaman tanaman berkhasiat obat yang diyakini oleh masyarakat dapat menyembuhkan penyakit. ${ }^{2}$ Masyarakat telah lama menggunakan tanaman berkhasiat obat untuk menyembuhkan penyakit. Pengetahuan tentang tanaman berkhasiat obat berdasarkan pada pengalaman dan keterampilan yang secara turun-temurun telah diwariskan dari satu generasi ke generasi berikutnya. ${ }^{3}$

Tanaman jambu biji (Psidium guajava L) merupakan salah satu tanaman berkhasiat obat yang diyakini oleh masyarakat. Daun jambu biji biasanya digunakan untuk mengobati sariawan, luka, haid tidak lancar, sembelit, maag, masuk angin, kanker, batuk, flu dan demam berdarah, bunganya berkhasiat untuk obat sakit kulit, buahnya biasanya digunakan untuk mengobati kencing manis, ranting mudanya biasanya digunakan untuk mengobati keputihan pada wanita, sedangkan akarnya digunakan untuk pengobatan disentri. Selain itu daun jambu biji biasanya dipakai untuk mengobati diare dengan dikunyah daunnya yang sebelumnya telah dibersihkan., ${ }^{4,5}$

Beberapa penelitian telah membuktikan bahwa tanaman jambu biji memiliki efek sebagai antioksidan, hepatoprotektif, antialergi, antiinflamasi, antihiperglikemia dan antimikroba. ${ }^{6-8}$ Penggunaan tumbuhan berkhasiat obat secara umum lebih aman dari pada penggunaan obat sintetik karena memiliki efek samping yang relatif sedikit jika digunakan secara tepat, yang meliputi kebenaran bahan, ketepatan dosis, ketepatan waktu penggunaan, ketepatan cara penggunaan, ketepatan telaah informasi, tanpa penyalahgunaan dan ketepatan pemilihan untuk indikasi tertentu. ${ }^{3}$

Di Indonesia daun jambu biji digunakan secara tradisional sebagai obat untuk menurunkan kadar kolesterol. $^{4}$ Berdasarkan data di atas maka peneliti tertarik untuk melakukan penelitian tentang efek ekstrak etanol daun jambu biji (Psidium guajava L) terhadap kadar kolesterol total tikus wistar.

\section{RUMUSAN MASALAH}

Apakah ekstrak etanol daun jambu biji (Psidium guajava L) berefek pada penurunan kadar kolesterol total tikus wistar yang diinduksi propiltiourasil?

\section{TUJUAN PENELITIAN}

Untuk mengetahui efek dari ekstrak daun jambu biji terhadap kolesterol total tikus wistar yang diinduksi propiltiourasil.

\section{METODOLOGI PENELITIAN}

Penelitian ini merupakan penelitian eksperimental dan dilaksanakan di Laboratorium Farmakologi dan Terapi Fakultas Kedokteran Universitas Sam Ratulangi Manado, pada bulan September 2012 s/d Januari 2013. Variabel independen: ekstrak etanol daun jambu biji. Variabel dependen: kadar kolesterol total.

\section{Definisi operasional}

1. Daun jambu biji yang digunakan dalam penelitian ini yaitu daun jambu biji yang berwarna hijau dan dipetik dari ranting pohon jambu biji secara acak di halaman kampus Fakultas Kedokteran Malalayang.

2. Hewan uji yang digunakan yaitu 15 tikus wistar dengan berat rata-rata 120 gram.

3. Obat yang dapat meningkatkan kadar kolesterol yang digunakan yaitu propiltiourasil sediaan tablet $100 \mathrm{mg}$.

4. Obat penurun kadar kolesterol yang digunakan yaitu simvastatin dengan sediaan tablet $10 \mathrm{mg}$.

5. Nilai patokan penurun kolesterol total ialah nilai kadar kolesterol total yang diukur setelah diinduksi dengan propiltiourasil selama 14 hari, dengan asumsi nilai kolesterol total sebelum diinduksi adalah normal.

\section{Alat dan bahan}

Alat yang digunakan dalam penelitian ini yaitu wadah plastik, kawat kasa, dedak 
padi, botol minum, Nasogastric tube (NGT) no 5, sarung tangan lateks, semprit $1 \mathrm{ml}$ dan $5 \mathrm{ml}$, gunting, oven, blender, cawan petri, timbangan digital, corong, batang pengaduk, kain penyaring, gelar ukur, alat Nescomulticheck dan nesco blood cholesterol test strip.

Bahan yang digunakan dalam penelitian ini yaitu tablet propiltiourasil @100mg, tablet @10 mg, daun jambu biji, kertas saring whatman no 1 , makanan (pelet) ayam/AD2, air, dan etanol 96\%.

\section{Prosedur penelitian}

Penelitian ini menggunakan beberapa prosedur, diantaranya sebagai berikut:

\section{Penyiapan hewan uji}

Penelitian ini menggunakan tikus wistar sebagai hewan uji, yang dibagi secara acak ke dalam 5 kelompok dan masing-masing kelompok tediri dari 3 ekor tikus wistar yang dipelihara dalam wadah yang ditaburi dedak padi dan bagian atasnya ditutupi dengan kawat kasa. Kelompok 1 sebagai kontrol positif, kelompok 2, 3 dan 4 sebagai kelompok eksperimental yang diberi ekstrak daun jambu biji dengan dosis $200 \mathrm{mg} / \mathrm{kgBB}, 400 \mathrm{mg} / \mathrm{kgBB}$ dan 800 mg/kgBB dan kelompok 5 sebagai kontrol negatif.

\section{Penentuan dosis propiltiourasil}

Dosis propiltiourasil (PTU) yang digunakan sebanyak $12,5 \mathrm{mg} /$ hari dibagi dalam 2 kali dosis pemberian selama 14 hari. $^{9}$ Propiltiourasil dibuat dalam bentuk larutan dengan cara melarutkan 100 mg PTU (1 tablet) dalam $8 \mathrm{ml}$ pelarut, sehingga dalam $1 \mathrm{ml}$ larutan terkandung 12,5 mg PTU.

\section{Penentuan dosis simvastatin}

Dosis simvastatin yang digunakan pada orang dewasa dengan berat rata-rata $50 \mathrm{~kg}$ yaitu $40 \mathrm{mg} /$ hari. Dosis simvastatin yang digunakan pada tikus dengan berat rata-rata 120 gram yaitu: $120 / 50000 \times 40=$ 0,096 mg, dibulatkan menjadi 0,1 mg. Simvastatin dibuat dalam bentuk larutan dengan cara melarutkan $10 \mathrm{mg}$ (1 tablet) simvastatin dalam $100 \mathrm{ml}$ pelarut (aquades), sehingga dalam $1 \mathrm{ml}$ terkandung $0,1 \mathrm{mg}$ simvastatin.

\section{Pembuatan ekstrak etanol daun jambu biji}

Daun jambu biji diambil sebanyak 2 kg, kemudian dicuci dengan air bersih, lalu dititiskan. Daun jambu biji yang telah bersih kemudian dikeringkan dalam oven pada suhu $40^{\circ} \mathrm{C}$ selama \pm 11 hari. Daun jambu biji yang telah kering di blender sampai menjadi serbuk. Serbuk daun jambu biji kemudian ditimbang lalu di rendam dengan etanol 96\% dengan perbandingan 150 gram serbuk dilarutkan dengan $500 \mathrm{ml}$ etanol, kemudian direndam selama \pm 5 hari, setiap hari dilakukan pengadukkan selama 15 menit. Setelah direndam, larutan yang diperoleh disaring dengan kain penyaring sehingga diperoleh filtrat dan debris. Filtrat hasil penyaringan dikumpulkan dalam gelas ukur kemudian disaring dengan kertas saring Whatman no.1 kemudian diletakkan dalam cawan petri untuk diuapkan dalam oven dengan suhu $40^{\circ} \mathrm{C}$ sampai didapatkan ekstrak pekat.

\section{Penentuan dosis ekstrak daun jambu biji}

Dosis ekstrak daun jambu biji yang digunakan yaitu 200 mg/kgBB, 400 mg/kgBB dan 800 mg/kgBB

\section{Cara pemberian ekstrak daun jambu biji,} propiltiourasil dan simvastatin

Ekstrak daun jambu biji, popiltiourasil dan simvastatin diberikan secara oral dengan menggunakan nasogastric tube (NGT) no.5 dengan semprit 1 cc dan dimasukkan melalui mulut sampai ke lambung, dimasukkan secara perlahanlahan untuk menghindari refluks.

\section{Perlakuan hewan uji}

Kelompok 1, 2, 3 dan 4 diberikan propiltiourasil selama 14 hari terlebih dahulu, sedangkan kelompok 5 hanya diberikan pakan biasa berupa pelet ayam (AD2). Kelompok 1 setelah pemberian PTU 
dilanjutkan dengan pemberian simvastatin sampai hari ke 28. Kelompok 2, 3 dan 4 setelah pemberian PTU dilanjutkan dengan pemberian ekstrak daun jambu biji masingmasing dengan dosis $200 \mathrm{mg} / \mathrm{kgBB}, 400$ $\mathrm{mg} / \mathrm{kgBB}$ dan $800 \mathrm{mg} / \mathrm{kgBB}$. penelitian ini dilaksanakan selama 29 hari. Pengukuran kadar kolesterol total dilakukan pada hari 1 , 8, 15, 22 dan 29.

\section{Pengambilan sampel darah}

Pengambilan sampel darah dilakukan di pembuluh darah kapiler dengan cara memotong bagian ujung ekot tikus dengan gunting. Sebelum pengukuran tikus dipuasakan terlebih dahulu selama 9-12 jam. Untuk mengukur kadar kolesterol total menggunakan alat nesco blood cholesterol test strip dan nesco multycheck.

\section{Analisis data}

Data yang diambil nantinya akan diolah menggunakan microsoft excel berupa tabel pada tiap kelompok dan gambar grafik rata-rata kadar kolesterol total pada tiap kelompok.

\section{HASIL PENELITIAN}

Tikus kelompok 1 sebagai kontrol positif, terdiri dari 3 tikus wistar yang diberi propiltiourasil (PTU) dengan dosis $12,5 \mathrm{mg} /$ hari selama 14 hari kemudian dihentikan dan dilanjutkan dengan pemberian simvastatin sebanyak $0,1 \mathrm{mg} /$ hari pada hari ke 15 sampai hari ke 28. Pengukuran kadar kolesterol dilakukan pada hari ke 1, 8, 15 (sebelum pemberian simvastatin), 22 dan 29 (Tabel 1, Gambar 1).

Tabel 1. Kadar kolesterol total kelompok 1, sebagai kontrol positif

\begin{tabular}{lccccc}
\hline & $\begin{array}{c}\text { Hari } \\
\text { ke 1 } \\
\text { (mg/dL) }\end{array}$ & $\begin{array}{c}\text { Hari } \\
\text { ke 8 } \\
(\mathbf{m g} / \mathbf{d L})\end{array}$ & $\begin{array}{c}\text { Hari } \\
\text { ke 15 } \\
(\mathbf{m g} / \mathbf{d L})\end{array}$ & $\begin{array}{c}\text { Hari } \\
\mathbf{k e ~ 2 2} \\
\mathbf{( m g / d L})\end{array}$ & $\begin{array}{c}\text { Hari ke } \\
\mathbf{2 9} \\
(\mathbf{m g} / \mathbf{d L})\end{array}$ \\
\hline Tikus 1 & 174 & 201 & 227 & 158 & 152 \\
Tikus 2 & 179 & 188 & 237 & 168 & 120 \\
Tikus 3 & 148 & 168 & 205 & 140 & 133 \\
Rerata & 167 & 185,67 & 223 & 155,33 & 135 \\
\hline
\end{tabular}

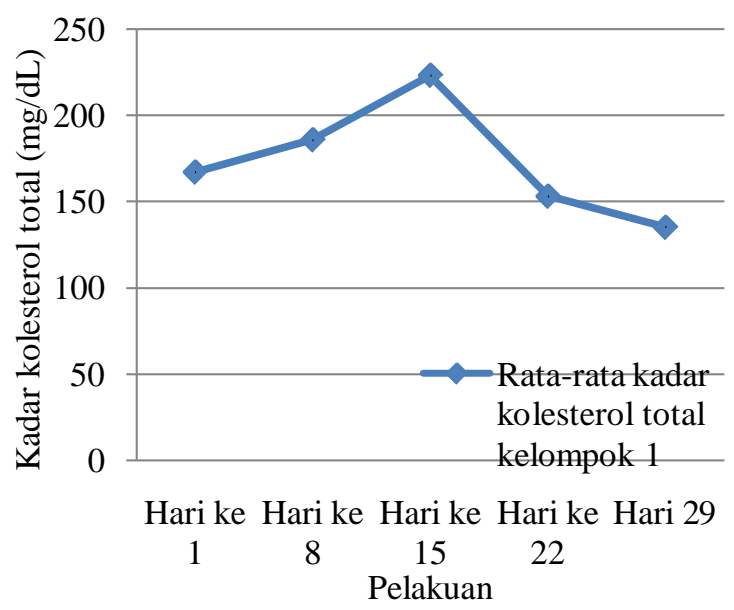

Gambar 1. Grafik rata-rata kadar kolesterol total tikus kelompok 1, sebagai kontrol positif

Tikus kelompok 2 terdiri dari 3 tikus wistar yang diberi PTU dengan dosis 12,5 $\mathrm{mg} /$ hari selama 14 hari kemudian dihentikan dan dilanjutkan dengan pemberian ekstrak etanol daun jambu biji dengan dosis $200 \mathrm{mg} / \mathrm{kgBB} / \mathrm{hari}$ dimulai pada hari ke 15 sampai hari ke 28. Pengukuran kadar kolesterol dilakukan pada hari ke 1, 8, 15 (sebelum pemberian ekstrak etanol daun jambu biji), 22 dan 29, hasilnya dapat dilihat pada Tabel 2 dan Gambar 2.

Tikus kelompok 3 terdiri dari 3 tikus wistar yang diberi PTU dengan dosis 12,5 mg/hari selama 14 hari kemudian dihentikan dan dilanjutkan dengan pemberian ekstrak etanol daun jambu biji dengan dosis $400 \mathrm{mg} / \mathrm{kgBB} / \mathrm{hari}$ dimulai pada hari ke 15 sampai hari ke 28. Pengukuran kadar kolesterol dilakukan pada hari ke 1, 8, 15 (sebelum pemberian ekstrak etanol daun jambu biji), 22 dan 29, hasilnya dapat dilihat pada Tabel 3 dan Gambar 3.

Tabel 2. Kadar kolesterol total kelompok 2

\begin{tabular}{lccccc}
\hline & $\begin{array}{c}\text { Hari } \\
\text { ke 1 } \\
(\mathbf{m g} / \mathbf{d L})\end{array}$ & $\begin{array}{c}\text { Hari } \\
\mathbf{k e} \mathbf{8} \\
(\mathbf{m g} / \mathbf{d L})\end{array}$ & $\begin{array}{c}\text { Hari } \\
\mathbf{k e ~ 1 5} \\
(\mathbf{m g} / \mathbf{d L})\end{array}$ & $\begin{array}{c}\text { Hari } \\
\mathbf{k e} \text { 22 } \\
(\mathbf{m g} / \mathbf{d L})\end{array}$ & $\begin{array}{c}\text { Hari } \\
\mathbf{k e} \text { 29 } \\
(\mathbf{m g} / \mathbf{d L})\end{array}$ \\
\hline Tikus 1 & 127 & 137 & 195 & 156 & 139 \\
Tikus 2 & 113 & 189 & 233 & 176 & 130 \\
Tikus 3 & 198 & 216 & 238 & 180 & 179 \\
Rerata & 148 & 180,67 & 222 & 170,67 & 149,33 \\
\hline
\end{tabular}




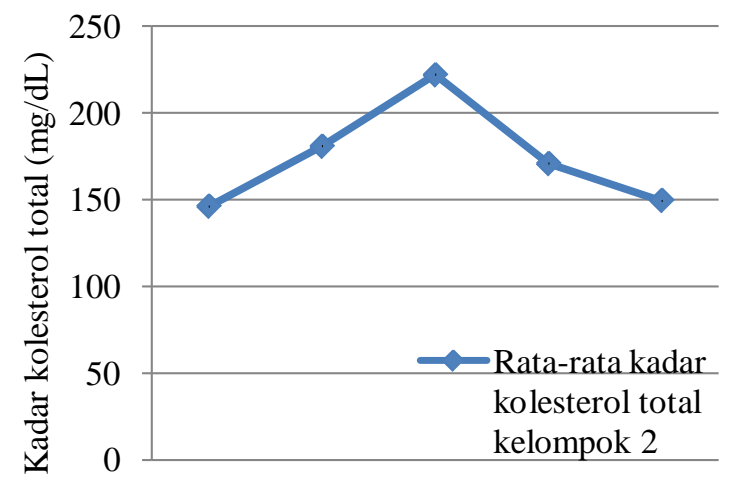

Hari ke Hari ke Hari ke Hari ke Hari 29 $\begin{array}{llcc}1 & 8 & 15 & 22 \\ & & \text { Perlakuan }\end{array}$

Gambar 2. Grafik rata-rata kadar kolesterol total tikus kelompok 2

Tabel 3. Kadar kolesterol total tikus kelompok 3

\begin{tabular}{|c|c|c|c|c|c|}
\hline & $\begin{array}{c}\text { Hari } \\
\text { ke } 1 \\
\text { (mg/dL) }\end{array}$ & $\begin{array}{c}\text { Hari } \\
\text { ke } 8 \\
(\mathbf{m g} / \mathbf{d L})\end{array}$ & $\begin{array}{c}\text { Hari } \\
\text { ke } 15 \\
\text { (mg/dL) }\end{array}$ & $\begin{array}{c}\text { Hari } \\
\text { ke } 22 \\
\text { (mg/dL) }\end{array}$ & $\begin{array}{c}\text { Hari ke } \\
29 \\
(\mathrm{mg} / \mathrm{dL})\end{array}$ \\
\hline Tikus 1 & 182 & 189 & 326 & 163 & 123 \\
\hline Tikus 2 & 199 & 239 & 293 & 130 & 128 \\
\hline Tikus 3 & 152 & 160 & 343 & 151 & 146 \\
\hline Rerata & 177,67 & 196 & 320,67 & 148 & 132,33 \\
\hline
\end{tabular}

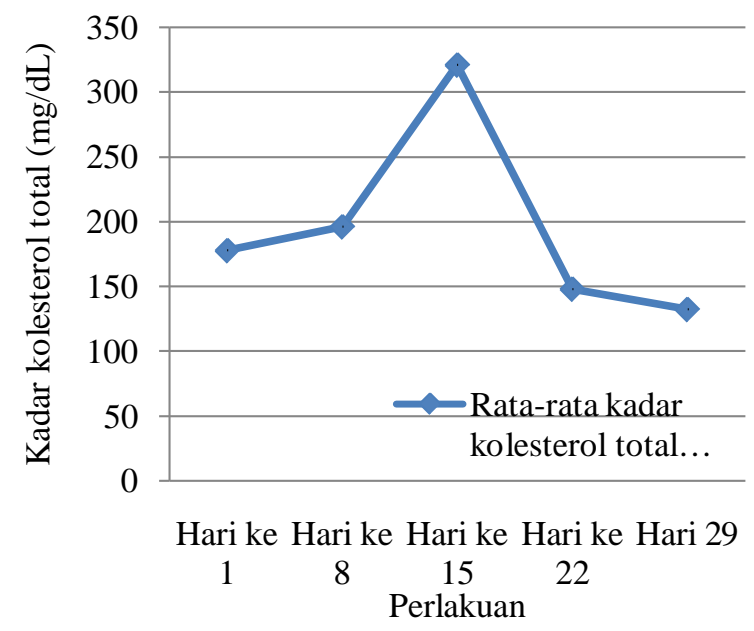

Gambar 3. Grafik rata-rata kadar kolesterol total tikus kelompok 3

Tikus kelompok 4 terdiri dari 3 tikus wistar yang diberi PTU dengan dosis 12,5 mg/hari selama 14 hari kemudian dihentikan dan dilanjutkan dengan pemberian ekstrak etanol daun jambu biji dengan dosis $800 \mathrm{mg} / \mathrm{kgBB} / \mathrm{hari}$ dimulai pada hari ke 15 sampai hari ke 28. Pengukuran kadar kolesterol dilakukan pada hari ke 1, 8, 15 (sebelum pemberian ekstrak etanol daun jambu biji), 22 dan 29, hasilnya dapat dilihat pada Tabel 4 dan Gambar 4.

Tabel 4. Kadar kolesterol total tikus kelompok 4

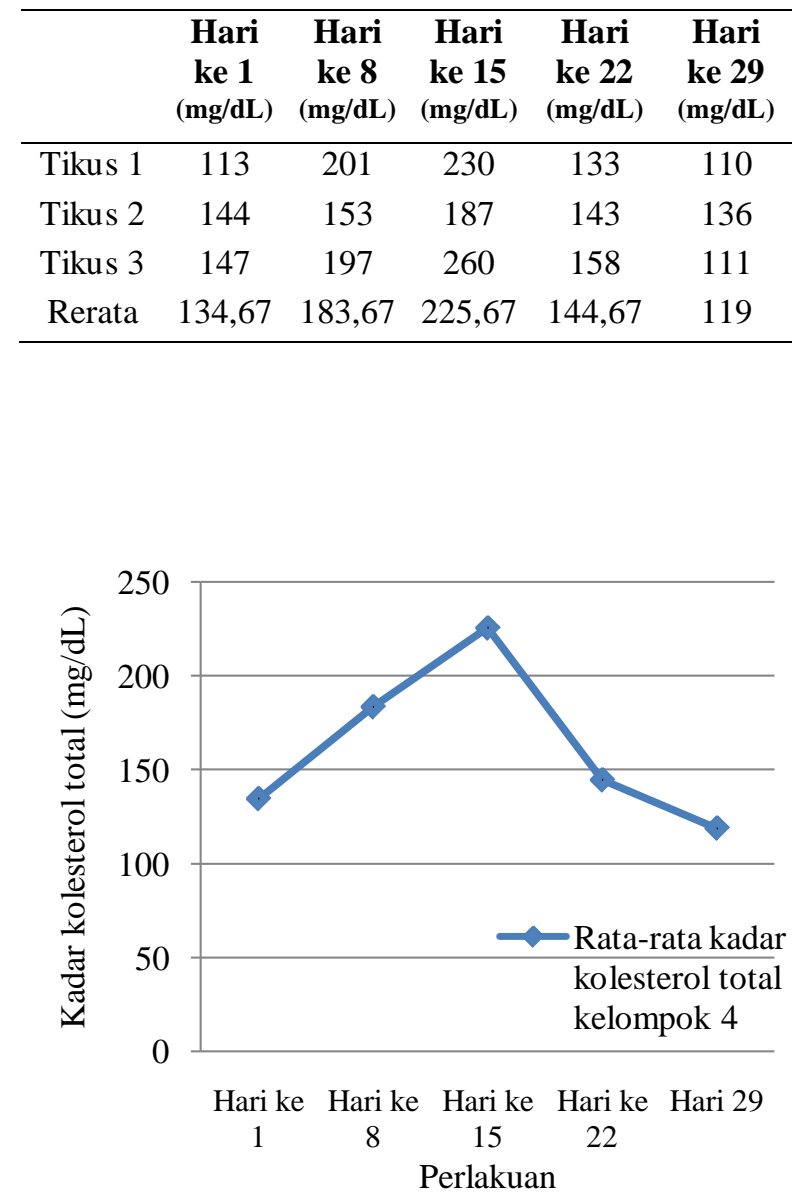

Gambar 4. Grafik rata-rata kadar kolesterol total tikus kelompok 4

Tikus kelompok 5 sebagai kontrol negatif, terdiri dari 3 tikus wistar yang tidak diberi PTU maupun ekstrak etanol daun jambu biji, hanya diberikan pakan standar. Pengukuran kadar kolesterol dilakukan pada hari ke 1, 8, 15, 22 dan 29, hasilnya dapat dilihat pada Tabel 5 dan Gambar 5. 
Tabel 5. Kadar kolesterol total tikus kelompok 5, sebagai kontrol negatif

\begin{tabular}{lccccc}
\hline & $\begin{array}{c}\text { Hari } \\
\text { ke 1 } \\
(\mathbf{m g} / \mathbf{d L})\end{array}$ & $\begin{array}{c}\text { Hari } \\
\mathbf{k e ~ 8} \\
(\mathbf{m g} / \mathbf{d L})\end{array}$ & $\begin{array}{c}\text { Hari } \\
\mathbf{k e} \text { 15 } \\
(\mathbf{m g} / \mathbf{d L})\end{array}$ & $\begin{array}{c}\text { Hari } \\
\mathbf{k e ~ 2 2} \\
(\mathbf{m g} / \mathbf{d L})\end{array}$ & $\begin{array}{c}\text { Hari ke } \\
\mathbf{2 9} \\
(\mathbf{m g} / \mathbf{d L})\end{array}$ \\
\hline Tikus 1 & 203 & 157 & 384 & 103 & 176 \\
Tikus 2 & 160 & 270 & 239 & 184 & 143 \\
Tikus 3 & 249 & 105 & 126 & 136 & 155 \\
Rerata & 204 & 177,33 & 249,67 & 141 & 158 \\
\hline
\end{tabular}

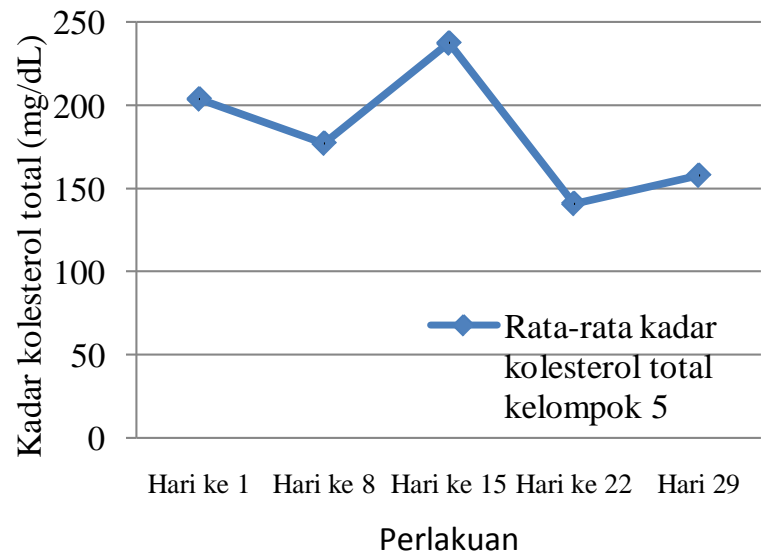

Gambar 5. Grafik rata-rata kadar kolesterol total tikus kelompok 5, sebagai kontrol negatif

Rata-rata kadar kolesterol total pada semua kelompok (kelompok 1, 2, 3, 4 dan 5) dapat dilihat pada Gambar 6.

\section{BAHASAN}

Penelitian ini menggunakan propiltiourasil sebagai obat untuk menaikkan kadar kolesterol. Dari hasil pengukuran kadar kolesterol total sebelum pemberian propiltiourasil rata-rata sebesar 156,34 $\mathrm{mg} / \mathrm{dL}$ dan setelah pemberian propiltiourasil rata-rata sebesar 247,84 $\mathrm{mg} / \mathrm{dL}$. Terjadi kenaikan kadar kolesterol total setelah pemberian propiltiourasil. Propiltiourasil akan menimbulkan hipotiroidisme yang di hubungkan dengan peningkatan konsentrasi LDL plasma akibat penurunan katabolisme LDL. Penyebabnya yaitu pada kondisi hipotiroid terjadi penurunan sintesis reseptor dan ekspresi LDL di hati, sehingga LDL banyak beredar di plasma dan menjadi penyebab hiperkolesterolemia. ${ }^{10}$

Hasil pengujian pada kelompok eksperimental (ekstrak daun jambu biji) yang diberi dosis $200 \mathrm{mg} / \mathrm{kgBB}, 400$ $\mathrm{mg} / \mathrm{kgBB}$ dan $800 \mathrm{mg} / \mathrm{kgBB}$ menunjukkan terjadi penurunan kadar kolesterol total sebesar 32,73\%, 58,73\% dan 47,26\%. Hasil penelitian ini menunjukkan bahwa ekstrak daun jambu biji memiliki efek menurunkan kadar kolesterol total. Hasil penelitian yang dilakukan Adeneye dan Olagunju (2009) membuktikan bahwa kandungan saponin dalam biji pepaya (Carica papaya L) memiliki efek dalam menurunkan kolesterol

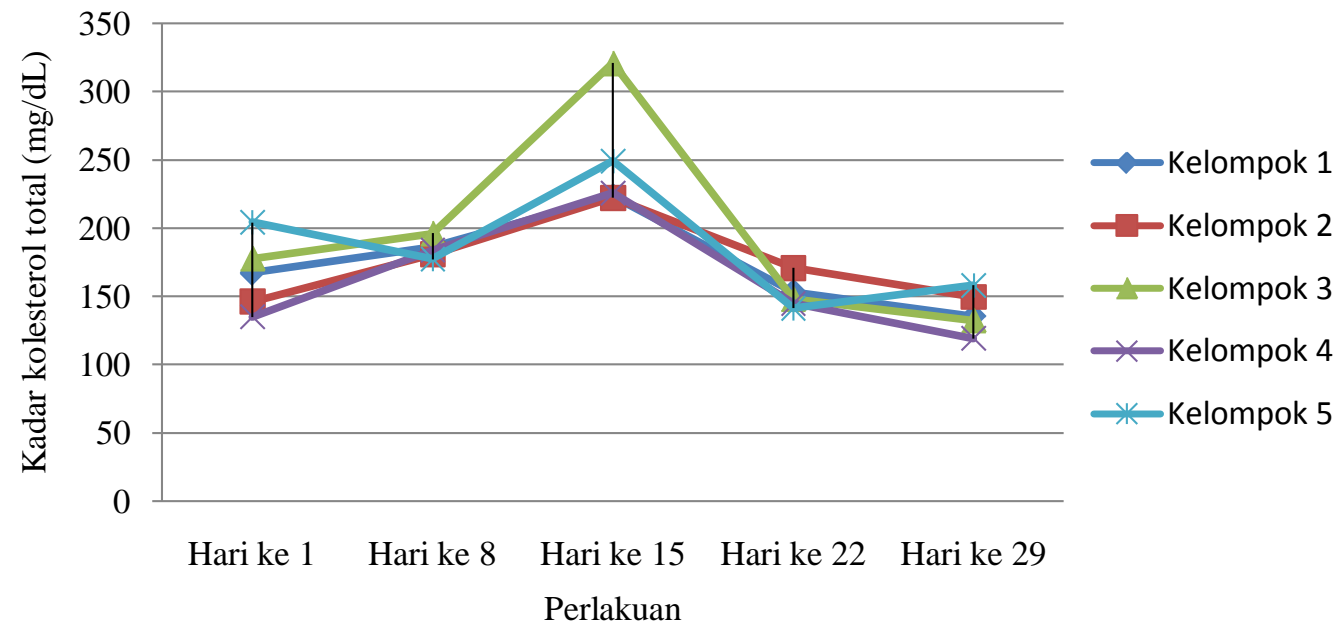

Gambar 6. Grafik rata-rata kadar kolesterol total semua kelompok 
total dengan cara mengikat asam empedu di usus sehingga proses enterohepatik tidak terjadi. ${ }^{11}$ tetapi apakah kandungan saponin pada daun jambu biji dan biji pepaya adalah sama atau berbeda, perlu dilakukan penelitian lebih lanjut.

Hasil pengujian pada kontrol positif yang diberi simvastatin menunjukkan terjadi penurunan kada kolesterol total akibat pemberian simvastatin sebesar 39,46\%. Penurunan kadar kolesterol total disebabkan oleh penurunan sintesis kolesterol di hati akibat penghambatan enzim HMG-KoA oleh simvastatin ${ }^{12}$

Pada kelompok kontrol negatif yang hanya diberikan makanan biasa dan aquades tanpa pemberian simvastatin maupun ekstrak daun jambu biji, terlihat bahwa kadar kolesterol total pada kelompok ini tidak stabil (ada yang naik dan ada yang turun). Hal yang mungkin mempengaruhi hasil yang diperoleh dari kontrol negatif yaitu belum mencapai galur murni, adanya perbedaan dalam kemampuan adaptasi terhadap lingkungan dan makanan yang selanjutnya dapat mempengaruhi pola makan dan aktifitas fisik tikus.

\section{SIMPULAN}

Berdasarkan hasil penelitian, didapatkan ekstrak daun jambu biji dengan dosis $200 \mathrm{mg} / \mathrm{kgBB}, 400 \mathrm{mg} / \mathrm{kgBB}$, dan 800 $\mathrm{mg} / \mathrm{kgBB}$ mempunyai efek dalam menurunkan kadar kolesterol total tikus wistar yang telah diinduksi propiltiourasil.

\section{UCAPAN TERIMA KASIH}

Ucapan terima kasih disampaikan pada Prof. dr. Jimmy Posangi, MSc, PhD, SpFK, DR. Dra. Fatimawali, Msi, Apt dan pada semua pihak yang baik secara langsung maupun tidak langsung telah menumbuhkan ide atau gagasan dalam pemikiran penulis sehingga dapat menyelesaikan artikel ini.

\section{DAFTAR PUSTAKA}

1. Hembing HM. Ramuan Lengkap Herbal Taklukan Penyakit [monograph online]. Jakarta: Pustaka Bunda, 2008; p.1. [cited 2012 Nov 14]. Available from: http://books.google.co.id/books?id=MPZr WtgMZ98C\&printsec=frontcover\&hl=id\& source=gbs_ge_summary_r\&cad $=0 \# v=$ one page \&q\&f=false

2. Nugroho IA. Lokakarya Nasional Tanaman Obat Indonesia; 2010 jul 28-30: Jakarta [homepage on the Internet]. 2010 [cited 2012 Nov 14]. Available from: http://forplan.or.id/images/File/Apforgen/N ewsletter/2010/LTOI\%20dan\%20Merbau\% 20PER\%20HAL.pdf

3. Kumala sari LOR. Pemanfaatan Obat Tradisional Dengan Pertimbangan Manfaat dan Keamanannya. J. Farmasi [serial online]. 2006 [cited 2012 Nov 15];3(1):1-7. Available from: http://journal.ui.ac.id/ index.php/mik/article/download/1155/1062

4. Marty T. Khasiat Istimewa Jambu Klutuk. Jakarta: Dunia sehat, 2012; p.44-9.

5. Dalimartha S. Atlas Tumbuhan Obat Indonesia Jilid 2. Jakarta: Trubus Agriwidya hal.73. [homepage on the Internet]. 2000 [cited 2012 Nov 17]. Available from: http://books.google.co.id/ books?id=vmrbQE4jfYcC\&printsec $=$ frontc over\&hl=id\&source=gbs_ge_summary_r\& $\mathrm{cad}=0 \# \mathrm{v}=$ onepage $\& \mathrm{q} \& \mathrm{f}=$ false

6. Indriani S. Aktifitas Antioksidan Ekstrak Daun Jambu Biji (Psidium guajava L). J. Pert.indon [serial online]. 2006 [cited 2012 Nov 15];11(1):13-7. Available from: http://repository.ipb.ac.id/bitstream/handle/ 123456789/46433/susi\%20indriani\%20\%20001.pdf

7. Deguchi Y, Miyazaki K. Antihyperglycemic and Anti-hyperlipidemic Effects of Guajava Leaf Extract. BioMed Central Ltd [serial online]. 2010 [cited 2012 Nov 19];7(9):3-10. Available from: http://www.biomedcentral.com/content/pdf 1743-7075-7-9.pdf

8. Chanu TR, Pai V, Chakraborty R, Raju $B$, Lobo R, Ballal M. Screening for Antidirrheal Aktivity of Psidium Guajava: A Possible Alternative In the Treatment Against Diarrhea Causing Enteric Pathogens. J. Chem. Pharm [serial online]. 2011 [cited 2012 Nov 19]; 3(6);961-967. 
Available from: http://jocpr.com/vol3-iss62011/JCPR-2011-3-6-961-967.pdf

9. Mantiri L. Gambaran Histologik Hati Tikus Wistar Yang Mengalami Hiperlipidemia Akibat Pemberian Propiltiourasil [Skripsi]. Manado: Unsrat; 2001; p.14-8.

10. Giri LN. Potensi Antioksidan Daun Salam: Kajian In Vivo Pada Tikus Hiperkolesterolemia dan Hiperglikemia [Skripsi]. Bogor: IPB; 2008; p.13.

11. Adeneye AA, Olagunju JA. Preliminary hypoglycimic and hypolipidemic activities of the aqueous seed extract of carica papaya linn in wistar rats. J. Biology and Medicine [serial online]. 2009 [cited 2013 Jan 15]; 1(1):1-10. Available from: http:// biolmedonline.com/Articles/vol1_1_110.pdf

12. Bagian Farmakologi dan Terapi Fakultas Kedokteran Universitas Indonesia. Farmakologi dan Terapi (Edisi Kelima). Jakarta: Balai penerbit FKUI, 2008; p.374,376,383,384,441,442. 